\title{
消化䤃素カプセル剤の腸溶性剂皮比較*1
}

\author{
开上良县, 大石輝雄, 品川龍太郎 \\ 東洋工業株式会社東洋病院薬局*2

\section{Comparison with Enteric Coated Films of Digestive Enzyme Capsules*1}

\author{
Yoshinori InOUe, TERUo OOISHI, RYUTARo SHINAGAWA \\ Pharmacy Section, Toyo Hospital of Toyo Kogyo Co., Ltd.*2
}

(Received February 2, 1982)

\begin{abstract}
The enteric coated granules contained in 10 kinds of commercial digestive enzyme capsules were examined for change with time of resistance in $\mathrm{pH} 5.0$ test solution and dissolution in $\mathrm{pH} 7.0$ solution. Changes of resistivity with time were recognized in nine samples. Furthermore, the enteric coated films of two samples were weakened with ime and were liable to rapid dissolution, whereas those of two other samples were hardened and interfered with enzyme dissolution. Consequently, it was suggested that one must be more careful about the change of the enteric coated films of digestive enzyme preparations with time than that of their activity.
\end{abstract}

Keywords—digestive enzyme; enteric coated films ; resistance against test solution

腸溶性製剤は医薬品の有効的利用の手段として多数市 販されている．特に消化酵素製剤は酵素活性保持のため 飞腸溶性剂皮の使用が一般的となっている.一方，飯沼 ら ${ }^{1)}$ が崩壊試験法（日局 8) の第 2 液で40４5分も要し て崩壊する製剤は，体内で崩壊せずに吸収部位を通過し てしまう技それがあると示唆しているように, 生体側の 状態によってはその剂皮の崩壊性不良が利用効率を低下 させる可能性も考えられる. 従って腸溶性製剂は $\mathrm{pH} \mathbf{5 . 0}$ で不変, 6.0 6.5で崩壊するのが望ましいと報告1 4)さ れているように, 胃内で内容物が溶出せず, 腸内ではす みやかに溶出するのが理想的である. しかし，一般的に 製薬会社の試験段階ではこの条件を満たしていても，流 通過程で経日的な変化が起こりらることは十分に考えら れる.

今回は，前報5) と同一条件下で保管された消化醳素カ プセル阂10品目の製造後経過年数の異なる数ロットにつ

*1 本報を「酵素製剈の力価比較」第 15 報とする．昭 和56年度中国四国薬学会病院薬学部会 (松山市)，で 発表.

*2 広島県安芸郡府中町青崎南2-15;2-15, Aosaki Minami, Fuchu-cho, Aki-gun, Hiroshima, 735 Japan
いて, 腸溶性顆粒の $\mathrm{pH}$ 5.0液に対する抵抗性と小腸上部 のpHである 7.02) での溶出性をアルカリ性プロテフーゼ を指標とした溶出曲線の作成によって調へ，腸溶性剂皮 の経日的変化を比較検討したので報告する.

\section{実 験 方 法}

\section{1. 試 料}

前報と同様に $25 \sim 28^{\circ} \mathrm{C}, \mathrm{RH} 50 \%$ の条件下で（最長 4 年間）保管された製造後0.2 4.5年経過の消化酵素カプ セル剤 10 品目, 43 ロットを試料とし, Table 1 に示し た。

\section{2. アルカリ性プロテアーゼ活性測定法}

$\mathrm{pH} 8.0$ でのプロテアーゼ活性をカゼインーフォーリン 法に準じた方法のによって測定した。

\section{3. 溶出曲線の作成}

3 Cap. の内容量を $\mathrm{pH} 5.0$ (または $\mathrm{pH} 7.0$ ) リン酸塩緩 衝液 $100 \mathrm{ml}$ 飞混和, $37 \pm 1^{\circ} \mathrm{C}$ の恒温槽に入れ, 10 分間 隔で静かに振とうしながら一定時間毎に上澄液を採り, 適宜水で希釈して試料液を調製後, そのアルカリ性プロ テアーゼ活性を求めた。な拢完全崩壊状態とするため, 内容物を乳鉢で泥状として調製された試料液の 活性を 
Table 1. Tested Preparations

\begin{tabular}{|c|c|c|c|c|c|c|c|}
\hline Capsule & Lot No. & Capsule & Lot No. & Capsule & Lot No. & Capsule & Lot No. \\
\hline \multirow{5}{*}{$\begin{array}{l}\text { Aczym } \\
(\mathrm{AC})\end{array}$} & $\mathrm{A} 00349 \mathrm{~N}$ & \multirow{6}{*}{$\begin{array}{l}\text { Excellase } \\
(\mathrm{EX})\end{array}$} & XECQ01 & \multirow{5}{*}{$\begin{array}{l}\text { Panatose } \\
\text { (PA) }\end{array}$} & \multirow{5}{*}{$\begin{array}{l}\text { HE107 } \\
\text { ID } 147 S\end{array}$} & \multirow{13}{*}{\multicolumn{2}{|c|}{\begin{tabular}{|ll} 
Toughmac E & F 019046 \\
(TE) & T28FF \\
& T 45GF \\
& F5041A \\
& F6054F
\end{tabular}}} \\
\hline & L10451 & & XECQ16 & & & & \\
\hline & $2 \mathrm{~A} 0477$ & & XECQ36 & & & & \\
\hline & $3 \mathrm{M} 0502$ & & XECQ44 & & & & \\
\hline & $4 \mathrm{M} 0524$ & & XECQ55 & & & & \\
\hline \multirow{3}{*}{$\begin{array}{l}\text { Berizym } \\
(\mathrm{BE})\end{array}$} & G910U & & XECQ68 & \multirow{5}{*}{$\begin{array}{l}\text { Seven } E \\
(\mathrm{SE})\end{array}$} & $874-5$ & & \\
\hline & NK02 & $\begin{array}{l}\text { Holmilase } \\
(\mathrm{HO})\end{array}$ & 1297S EB & & $888-1$ & & \\
\hline & TB15 & \multirow[t]{2}{*}{$(\mathrm{HO})$} & 1411SDD & & $900-3$ & & \\
\hline \multirow{5}{*}{$\begin{array}{l}\text { Feltase } \\
\text { (FE) }\end{array}$} & 01901 & & $1426 \mathrm{SGD}$ & & $905-2$ & & \\
\hline & 07012 & \multirow{4}{*}{$\begin{array}{l}\text { Politose } \\
\text { (PO) }\end{array}$} & 0525 & & $913-4$ & & \\
\hline & 01803 & & 0707 & Stomilase & EC275 & & \\
\hline & 01804 & & 0766 & $(\mathrm{ST})$ & FH315 & & \\
\hline & 01805 & & 0720 & & & & \\
\hline
\end{tabular}

$100 \%$ とし，アルカリ性プロテアーゼ溶出曲線を作成し た。

\section{実験結果と考絮}

$\mathrm{pH} 5.0$ 液に対する昘皮の抵抗性と $\mathrm{pH} 7.0$ での溶出性の 経日的変化を調べるために，各製剤の新旧ロットについ て各々のアルカリ性プロテアーゼ溶出曲線を作成し, 困 1～図10に示した.（）内は製造後の経過年数，〔] 内は使用期限（年数）を示す．なお，泥状とした最新口 ットの $\mathrm{pH}$ 5.0液における活性変化を同時に図示し，この 曲線との比較によって抵抗性を検討した．また $\mathrm{pH} 7.0$ 液 での泥状試料の活性変化は $37^{\circ} \mathrm{C}, 120$ 分間にほとんど認 められないことを確認したので, 図示を省略した。

1. AC (Fig. 1)

本剤は $\mathrm{pH} 7.0$ 液で全口ットが 30 分以内に 崩壊し溶出 性に差が認められなかったので $\mathrm{pH} 5.0$ 液の場合のみを図 示した。

剂皮の抵抗性はDとEを比較した場合, 経日変化が認 められるが， 1 年以上経過したロットは経過年数による 差はわずかである. しかし最新の製品 Eでも60分值が60 \%以上の溶出であることから本剤は腸溶性製剤とはいい 難いと考える。な扮田部ら7) も同様の結果を報告してい る.

\section{BE (Fig. 2)}

経日変化は抵抗性, 溶出性ともに認められず, 先に述 べた腸溶性製剤としての条件をも満たす7) 優れた製剤で ある.

\section{EX (Fig. 3)}

最近ロットの抵抗性は非常に優秀であるが経過年数と ともに劣化している．このために pH7.0での酵素溶出は 速くなり，斉皮は次第に軟弱となることが推察される。 なお本凧は使用期限の表示がされていないが, 経日的活 性変化が小さいこと,5) および斉皮の抵抗性から判断し て，製造後 2.0 年が使用限度と考えられる。

4. FE (Fig. 4)

斉皮の抵抗性は D，E曲線から非常に優れていること がわかる．しかし使用期限を過ぎると劣化が早いことか ら，2.0 年の使用期限設定は 妥当と考える. また $\mathrm{pH} 7.0$ 液での溶出はすみやかで経日変化すないために，本剤の 腸溶性剂皮は BEより上位に評価できる.

5. HO (Fig. 5)

剂皮の抵抗性に経日変化をほとんど認めない。しかし AC よりも抵抗性はあるが 120 分後には約 $50 \%$ の酵素が 溶出しており，一般的に医薬品は服用後 60１20 分で小 腸上部に到達する8)ことから，腸溶性剂皮としての機能 は不十分と考えられる. また溶出性は Fig. 5 に示すよ らに経過年数とともに速くなることから，EX と同様に 剤皮は次第にもろくなっていることが推察される。

6. ST (Fig. 6)

斉皮の腸溶性としての機能は優れているとはいい難い が, 経日変化は小さい製剤である. 永瀬らの報告9)とは 異なり, 溶出性にも経口変化が認められていない。

7. PA (Fig. 7)

製造後 1 年以内の製品の抵抗性は強固であるが 2 年以 
上のものは非常に劣化している.しかし溶出性は使用期 限内で経日変化が認められないことから, すら一歩の改 善が必要と考えられる。

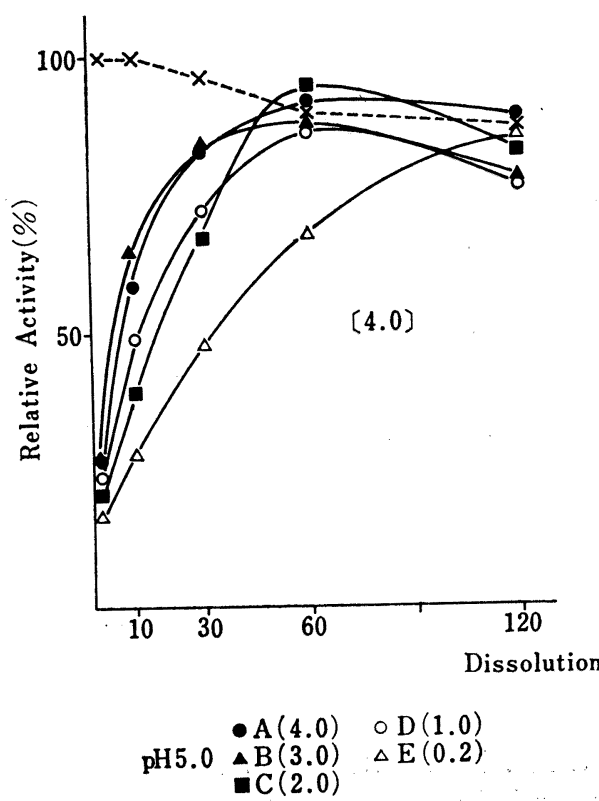

$x---x$ crushed sample

Fig. 1. Dissolution Curves of AC

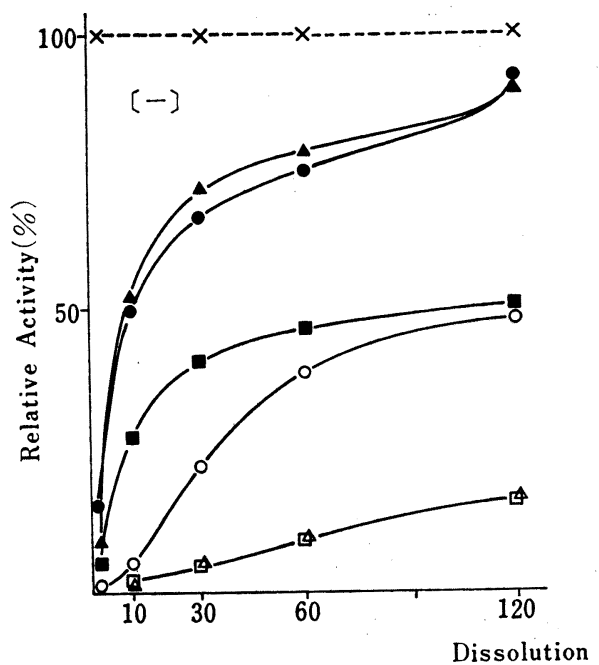

pH 5.0

Dissolution Time (min)

- $\mathrm{A}(4.5) \Delta \mathrm{B}(3.5) \square \mathrm{C}(2.3) \circ \mathrm{D}(1.8) \Delta \mathrm{E}(1.0) \quad \mathrm{F}(0.2)$

$x---x$ crushed sample

Fig. 3. Dissolution Curves of EX
8. PO (Fig. 8)

本剂は永瀬ら”）指摘しているように，斉皮の抵抗性 は年々劣化しているが，使用期限内では 120 分後でも 35

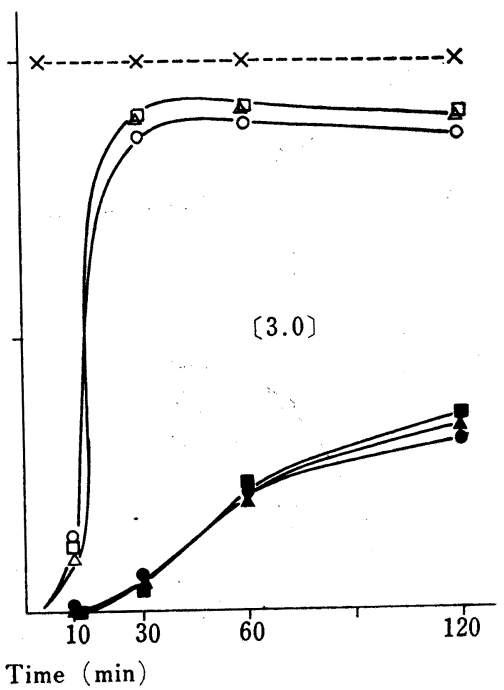

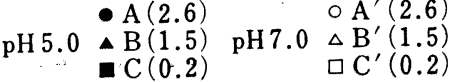

Fig. 2. Dissolution Curves of BE

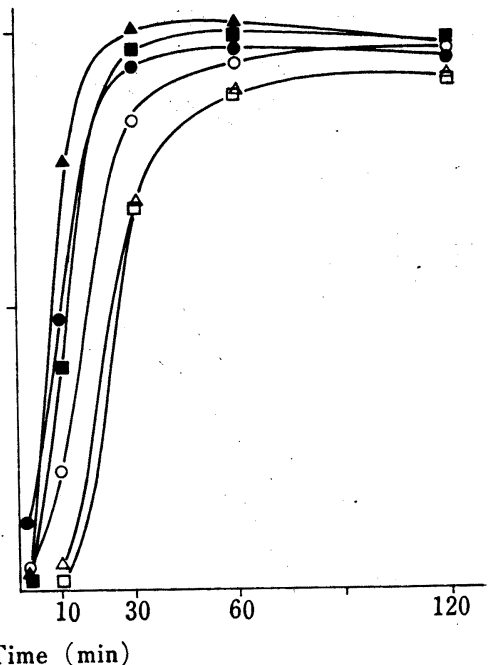

$\mathrm{pH} 7.0$ 
\%以内の溶出であり, 他剂と比較した場合はかなり優れ た製剤と思われる。 また溶出性は良好で経日变化む認め られず，非常に厳しく管理された製剤である。

9. SE (Fig. 9)

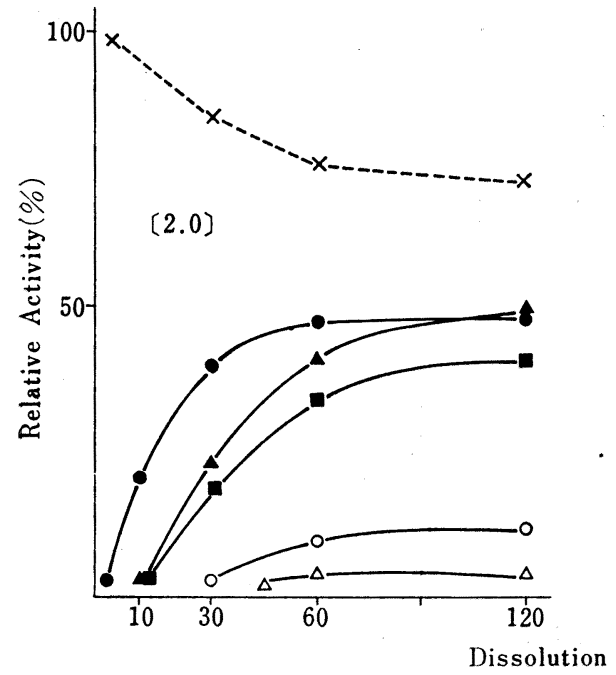

$\mathrm{pH} 5.0$
本剤の $\mathrm{D}, \mathrm{E}$ と C とは極端に抵抗性が異なり，1 年程 度で急速に剤皮が劣化することが推察される．また最新 ロットEす60分以後に急速な溶出が認められることから 剂皮の改良が望まれる.永瀬ら92 1 年保存の製品はpH

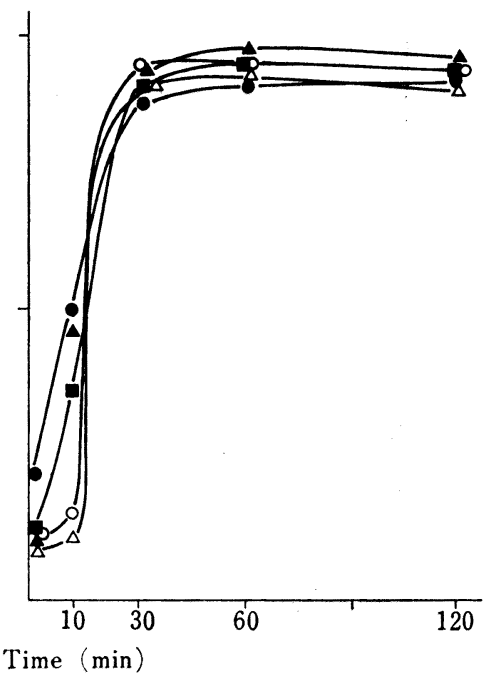

$\mathrm{pH} 7.0$

- $\mathrm{A}(4.5) \Delta \mathrm{B}(3.4) \backsim \mathrm{C}(2.7) \circ \mathrm{D}(1.7) \Delta \mathrm{E}(0.7)$ $x---x$ crushed sample

Fig. 4. Dissolution Curves of FE
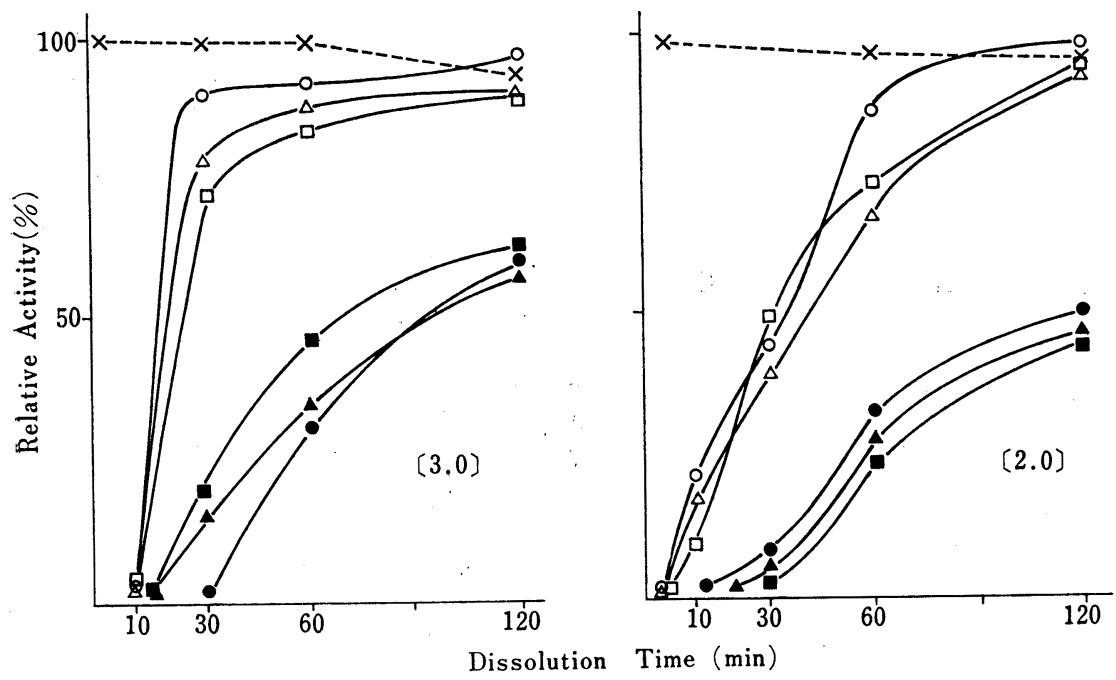

$$
\begin{aligned}
& \text { - } \mathrm{A}(2.8) \\
& \circ \mathrm{A}^{\prime}(2.8)
\end{aligned}
$$

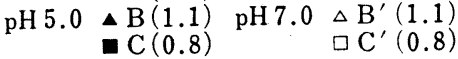

- $\mathrm{A}(3.3) \quad \circ \mathrm{A}^{\prime}(3.3)$

$\mathrm{pH} 5.0 \Delta \mathrm{B}(2.2) \quad \mathrm{pH} 7.0 \Delta \mathrm{B}^{\prime}(2.2)$ - $\mathrm{C}(1.0)$ $\square C^{\prime}(1.0)$

$x---x$ crushed sample

Fig. 5. Dissolution Curves of HO

Fig. 6. Dissolution Curves of ST 
5.0 で30分後に溶出の完了を認めているが，本実験では 30\%程度が残存していることをC 曲線が示している。 た溶出性にも明らかな差異が認められ，1年以内のロッ トなら60分以内にほぼ溶出が完了するが， A, B 曲線が

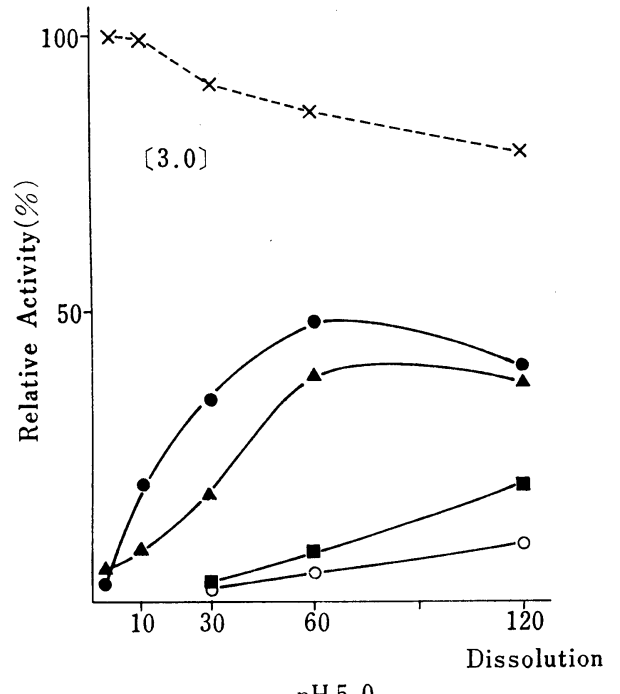

$\mathrm{pH} 5.0$

- $\mathrm{A}(3,0), \mathrm{B}(2,0)$

$x---x$ crushed sample

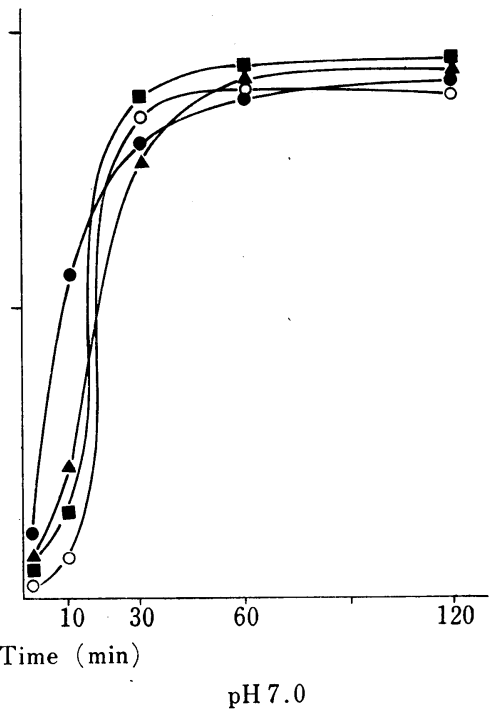

Fig. 7. Dissolution Curves of PA
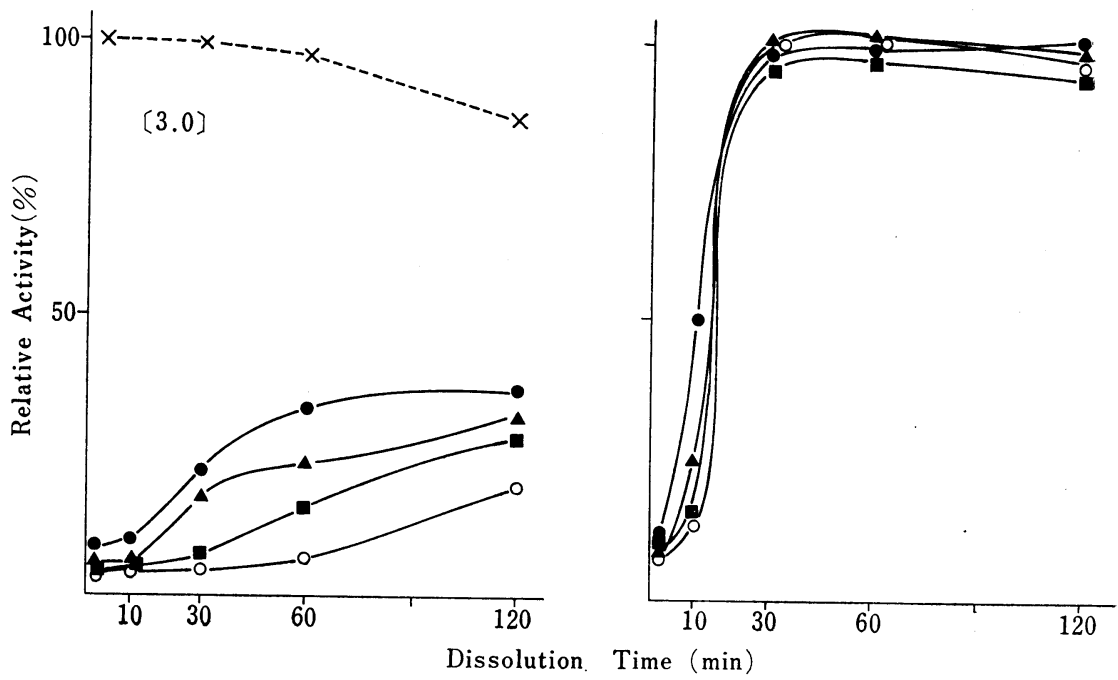

pH 5.0

- $\mathrm{A}(2.6) \Delta \mathrm{B}(1.3) \quad \mathrm{C}(0.5) \circ \mathrm{D}(0.2)$

$\mathrm{pH} 7.0$

Fig. 8. Dissolution Curves of $\mathrm{PO}$
示すように経過年数とともに溶出性は悪くなることがわ

10. TE (Fig. 10) 
本剤も経過年数に従って抵抗性が劣化している。しか も最新ロット $\mathrm{E} 330$ 分後から 溶出し始め, 120 分後には $50 \%$ の溶出が認められる。.また溶出性は D, E と A〜C
曲線との間に明らかな差異があり，1.3 年 (D) 以上では 10〜20\%が溶出し得ない状態となり，永瀬ら ${ }^{9)}$ の報告と 類似した結果が得られている.

$$
\text { 20 }
$$
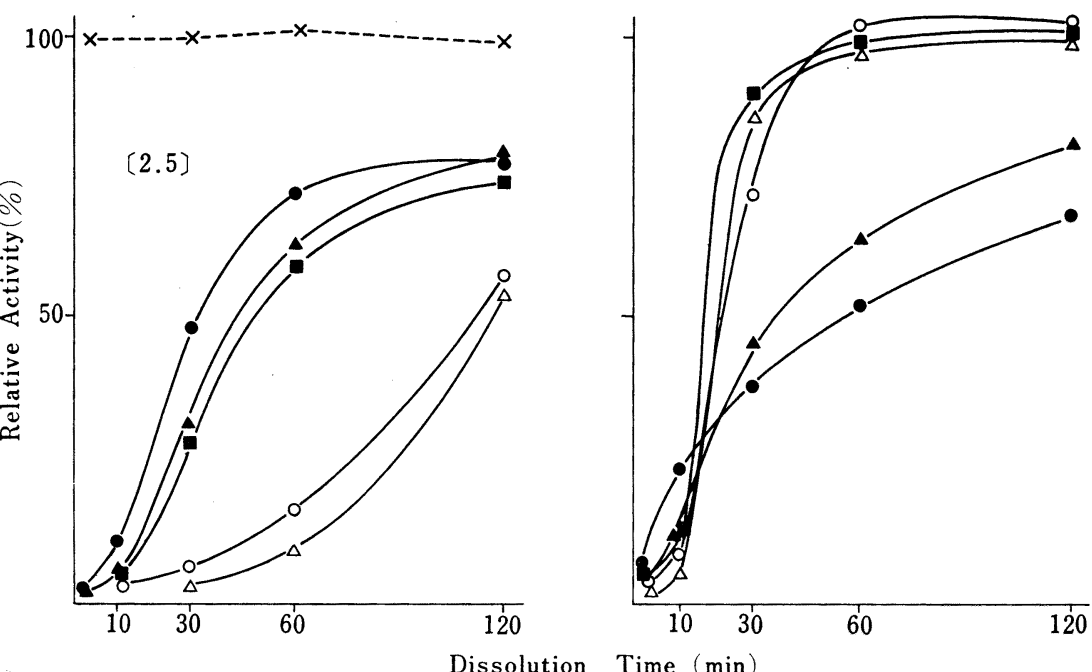

$\mathrm{pH} 5.0$

- $\mathrm{A}(3.6) . \Delta \mathrm{B}(2.2) \backsim \mathrm{C}(1.1) \circ \mathrm{D}(0.5) \Delta \mathrm{E}(0.2)$

$$
\times---x \text { crushed sample }
$$

Fig. 9. Dissolution Curves of SE
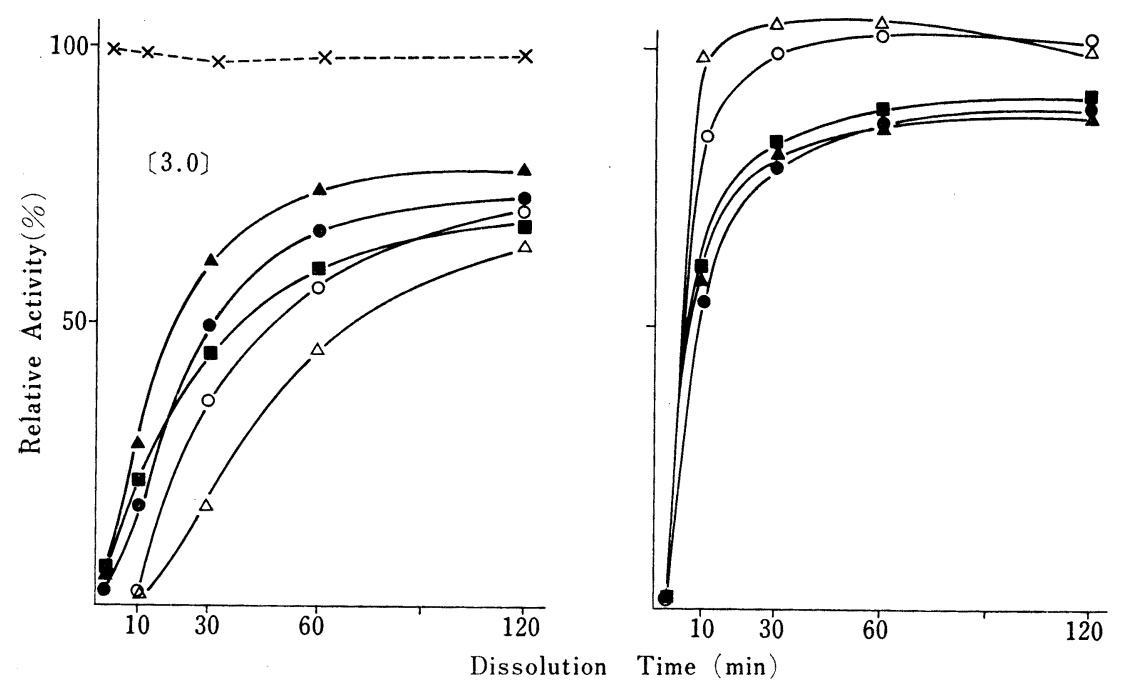

$\mathrm{pH} 5.0$

$\mathrm{pH} 7.0$

- $\mathrm{A}(3.3) \Delta \mathrm{B}(2.5) \quad \mathrm{C}(2.0) \circ \mathrm{D}(1.3) \Delta \mathrm{E}(0.2)$

$x---x$ crushed sample

Fig. 10. Dissolution Curves of TE 
結

論

1. 剂皮の抵抗性に関しては, 程度の差はあるが, $\mathrm{BE}$ 以外の 9 品目で経日变化が認められた。特に製造後 1 年以上と 1 年以内のロット間差が顕著であった. また $\mathrm{BE}, \mathrm{FE}, \mathrm{PO}$ の 3 品目以外の製剂は $\mathrm{pH} 5.0$ 液に対する 抵抗性が弱く, 腸溶性剂皮としては改善の余地があると 思われた。

2. 溶出性に関しては, 経日変化を認めなかった製剤 (AC, BE, FE，PA，PO，ST) と認められた製剂 (EX, HO, SE，TE）があった. EX, HO は溶出が経日的に速 くなり，反対に SE，TE は遅くなる傾向にあった。す なわち前 2 者は剂皮がもろくなり, 後 2 者は固くなって 完全には溶出が完了乙得ない状態となっていることが推 察された。

以上の結果から, 消化酵素製剂は活性の経日変化 ${ }^{5)}$ 以 上に腸溶性顆粒の剂皮が变化していることに留意して， 使用期限内であってもできるだけ新しい製品（少なくと
も製造後 6 カ月以内）を使用できるように管理する必要 があると思われた。

交献

1）飯沼龍一, 蔦谷有甫, 土田和男, 沢野昭三 : JNHPA, 10, 223 (1974).

2) 飯沼龍一, 遠山富也：薬剤学, 21, 48 (1961).

3）前川秀幸, 高岸 靖, 土居義男: 薬剤学, 30 , 102 (1961).

4) 佐藤 登, 宮本保男, 内山芳朗 : 薬剤学, 36, 22 (1976).

5）井上良則, 大石輝雄, 品川龍太郎: 病院薬学, 7, 253 (1981).

6) 井上良則, 六石輝雄, 角井修子, 尾崎 亮 : JNHPA, 7, 13 (1974).

7) 田部和久, 門村宗男, 畑田昭男, 平岡栄一：病院 薬学, 6, 21 (1980).

8）飯沼龍一, 䳺谷有甫, 土田和男, 宮川肇, 沢野 昭三：JNHPA, 8 (6), 4 (1972).

9）永瀬一郎, 藤代とし, 岡本尚子, 金久保好男 : 病 院薬学, 6, 110 (1980).

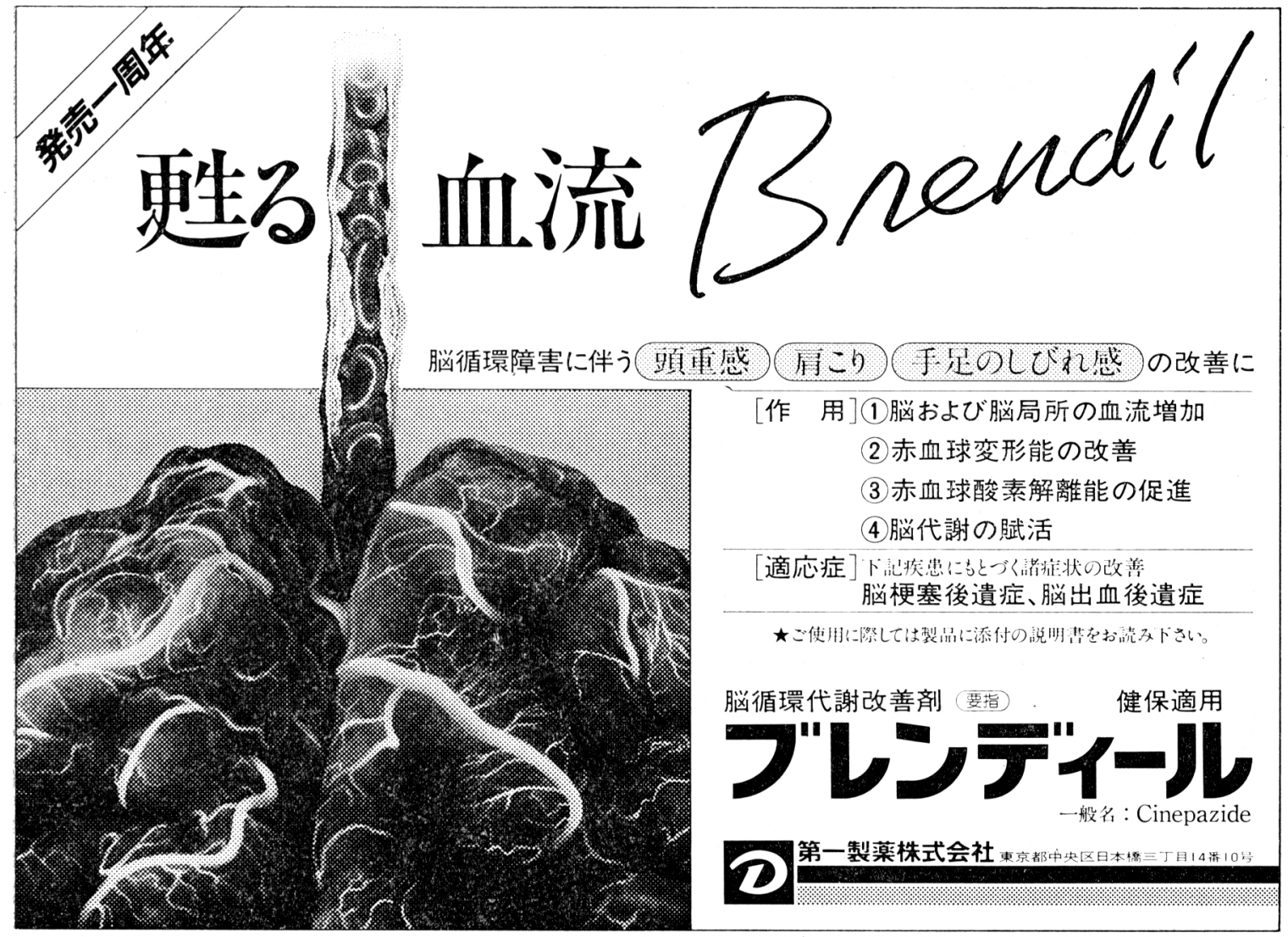

